\title{
MEDICINE
}

\section{ДИНАМІКА МОРФОЛОГІЧНИХ ЗМІН СТРУКТУРНИХ КОМПОНЕНТІВ ХРЯЩОВОГО ПОКРИТТЯ КОЛІННОГО СУГЛОБА НА УЛЬТРАСТРУКТУРНОМУ РІВНІ НАПРИКІНЦІ ПЕРШОГО, ДРУГОГО ТА ТРЕТЬОГО ТИЖНІВ ОПІӦ̈ДНОГО ВПЛИВУ}

\author{
Войценко К. І., Пальтов Є. В., Кривко Ю. Я., Голейко М. В. \\ Львівський національний медичний університет імені Данила Галищького, кафедра нормальної \\ анатомії, м. Львів, Украӥна
}

DOI: https://doi.org/10.31435/rsglobal_sr/31012019/6334

\section{ARTICLE INFO}

Received 12 November 2018

Accepted 27 January 2019

Published 31 January 2019

\section{KEYWORDS}

experimental opioid exposure, rat,

knee joint, articular cartilage.

\begin{abstract}
The work presented below, aimed at studying the onset, development and manifestations of pathomorphic chondropathy in acute and subchronic experimental exposure of opioid analgesics. The objective was achieved by using microscopic visualization technique of cellular components of the articular cartilage. To obtain the microstructural materials we applied generally accepted, conventional methods.

The results of the study in the future will allow to form a pathomorphological basis, which can be used for a comparative characterization of the structural components of the articular cartilage of the knee joint in the early and late stages (acute and subchronic) of experimental opioid exposure.
\end{abstract}

Citation: Войценко К. І., Пальтов С. В., Кривко Ю. Я., Голейко М. В. (2019) Dynamika Morfolohichnykh Zmin Strukturnykh Komponentiv Khriashchovoho Pokryttia Kolinnoho Suhloba na Ultrastrukturnomu Rivni Naprykintsi Pershoho, Druhoho ta Tretoho Tyzhniv Opioidnoho Vplyvu. Science Review. 1(18). doi: 10.31435/rsglobal_sr/31012019/6334

Copyright: (C) 2019 Войценко К. І., Пальтов С. В., Кривко Ю. Я., Голейко М. В. This is an openaccess article distributed under the terms of the Creative Commons Attribution License (CC BY). The use, distribution or reproduction in other forums is permitted, provided the original author(s) or licensor are credited and that the original publication in this journal is cited, in accordance with accepted academic practice. No use, distribution or reproduction is permitted which does not comply with these terms.

Результати статі відповідають плану наукових досліджень Львівського національного медичного університету імені Данила Галицького і є частиною науково-дослідної теми кафедри нормальної анатомії «Структурна організація, ангіоархітектоніки та антропометричні особливості органів у внутрішньо та позаутробному періодах розвитку, за умов екзо- та ендопатогених факторів» (номер держреєстрації 0115U000041) впродовж 2015 - 2019 рр.

Вступ. Актуальність вивчаємої теми в повному об'ємі висвітлює жахаючий ріст статистичних даних щодо неконтрольованого вживання наркотичних препаратів фармацевтичного та сурогатного виробництва. За останні роки досить велика кількість публікацій присвячена проблемі неконтрольованого вживання сильнодіючих та психотропних препаратів $[1,2]$. Зокрема дослідження стосуються наслідків їх негативного впливу в результаті довготривалого вживання та дифдіагностики цих наслідків в залежності від походження препарату (опіоїди медикаментозного та сурогатного кустарного походження) [3, 4].

Незважаючи, що у літературі існують повідомлення про патоморфологічні зміни у ряді органів та систем на тлі опіоїдного впливу [5 - 16] і досі лишається нез'ясованим питання опіоїдної ангіохондродистрофії. Зокрема до кінця нез'ясованим лишається питання плавності 
наростання і глибини ангіо- та хондродистрофій на різних термінах експериментального опіоїдного впливу. Вищезазначене окреслело мету нашої роботи, що полягала у вивченні особливостей структурної дезорганізації структурних компонентів хрящового покриття колінного суглоба на ультраструктурному рівні наприкінці 1, 2 та 3-го тижнів експериментального опіоїдного впливу.

Матеріали та методи дослідження. Матеріалом дослідження слугували статево зрілі, безпородні щури-самці в кількості 32-ві тварини, масою 80 - 103 г, віком 4,5 місяців. Тваринам проводили ін'єкції препарату налбуфін дом'язево, щоденно 1 раз на добу в одному проміжку часу (10-11 година ранку) впродовж 21 доби. Початкова доза налбуфіну становила 8 мг/кг впродовж першого тижня, 15 мг/кг впродовж другого тижня та 20 мг/кг впродовж третього тижня. Таким чином створювали умови хронічного опіоїдного впливу [17]. Тварини поділені на 4 групи. 1-а група тварин отримувала налбуфін протягом 7 діб в одному проміжку часу (10 - 11 годин ранку) 3 наступним забором матеріалу дослідження (кінець 1-го тижня експериментального опіоїдного впливу); 2-а група тварин отримувала налбуфін протягом 14 діб в одному проміжку часу (10 - 11 годин ранку) з наступним забором матеріалу дослідження (кінець 2-го тижня експериментального опіоїдного впливу); 3-а група тварин отримувала налбуфін протягом 21 доби в одному проміжку часу (10 - 11 годин ранку) з наступним забором матеріалу дослідження (кінець 3-го тижня експериментального опіоїдного впливу); 4-а контрольна, яка протягом 21 доби отримувала ін'єкції фізіологічного розчину дом'язево в одному проміжку часу (10-11 годин ранку). Усі тварини знаходились в умовах віварію і робота, що стосувалася питань утримання, догляду, маркування та всі інші маніпуляції проводилися із дотриманням положень «Европейської конвенції про захист хребетних тварин, які використовуються для експериментальних та інших наукових цілей» [Стразбург, 1985], “Загальних етичних принципів експериментів на тваринах”, ухвалених Першим Національним конгресом з біоєтики [Київ, 2001]. Комісією з біоєтики Львівського національного медичного університету імені Данила Галицького встановлено, що проведені наукові дослідження відповідають етичним вимогам згідно наказу МО3 України № 231 від 01.11.2000 року (протокол № 10 від 26.12.2011 року). Перед проведенням забору біопсійного матеріалу тварину присипляли дибутиловим ефіром. Як матеріал для ультраструктурного дослідження використали хрящі дистального епіфізу стегнової та проксимального епіфізу великогомілкової кісток колінного суглоба щурів. Ультраструктурні препарати готували за загальноприйнятою методикою [18 - 20].

Результати дослідження. В результаті ультраструктурного дослідження клітинного складу хрящового покриття колінного суглоба експериментальної групи тварин наприкінці 7-ї доби під впливом опіоїдного анальгетика в дозі 8 мг / кг на ультраструктурному рівні нами було виявлено неоднорідне, інтенсивно осміофільне забарвлення безклітинної пластинки суглобового хряща. Суглобова поверхня була нерівною, на ній з'являлись заглиблення. В окремих ділянках спостерігали розволокнення та руйнування фібрил колагенових волокон. Досить часто колагенові волокна розташовувались нещільно, хаотично. Осередки розволокнення колагенового каркасу частіше локалізувались у периферичних зонах суглобової поверхні. У хондроцитах поверхневої зони відзначали ознаки деструкції цитоплазми. Зокрема, реєстрували розширення та фрагментацію канальців гладкої ендоплазматичної сітки як це видно на рис.1.

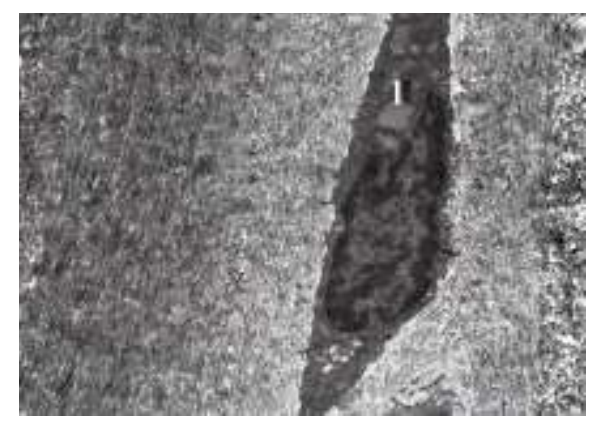

Рис. 1. Хондроцит хряща колінного суглоба дистального кіния стегнової кістки щура наприкінці 7-ої доби опіоїдного впливу. Мікрофотографія. 3б. х6000.

1 -розширення канальиів гладкої ендоплазматичної сітки хондроцита поверхневої зони. 
У ділянках контакту поверхневої та перехідної зони матрикс був просвітленим, набряклим з ділянками розшаруння, фібрили колагенових волокон розташовувались хаотично. У окремих хондроцитах перехідної зони виявили ознаки дегенеративних, а іноді некротичних змін. У ядрі збільшувалась кількість гетерохроматину. Спостерігали розширення цистерн гладкої та гранулярної ендоплазматичної сітки. як це показано на рис.2.

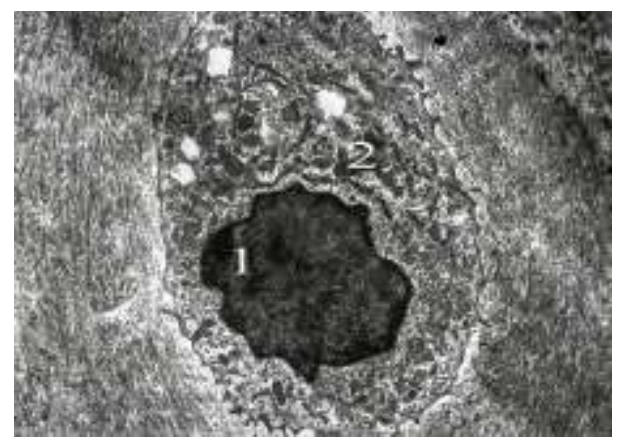

Рис. 2. Хондрочит хряща колінного суглоба перехідної зони щура наприкінщі 7-ої доби опіоїдного впливу. Мікрофотографія. 3б. х8000.

1 - збільшення кількості гетерохроматину в ядрі хондроцита перехідної зони; 2 - розширення цистерн гладкої ендоплазматичної сітки.

У перинуклеарній зоні, а місцями і в периферичних ділянках цитоплазми виявляли вакуолі, що були заповнені електронносвітлим вмістом як це видно на рис.3. Спостерігали руйнування рибосом гранулярної ендоплазматичної сітки. В окремих хондроцитах перехідної зони відзначали виражену деструкцію органел як це показано на рис.4, у цитоплазмі збільшувалась кількість гранул глікогену.

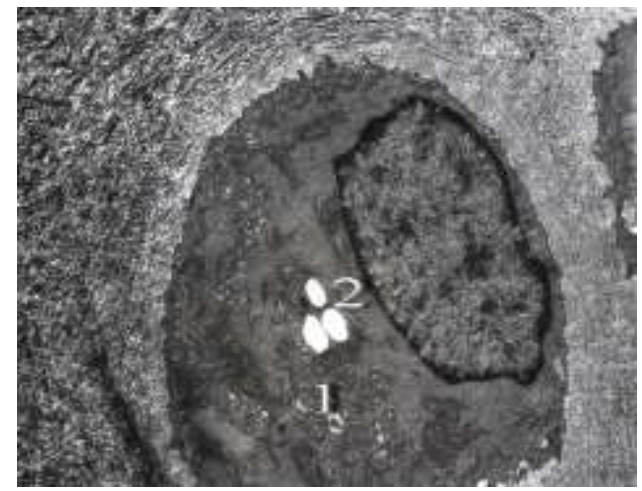

Рис. 3. Ділянка перехідної зони хряща колінного суглоба щура наприкінщі 7-ої доби опіоїдного впливу. Мікрофотографія. 3б. х 6000.

1 - руйнування рибосом гранулярної ендоплазматичної сітки.; 2 - вакуолі у ичитоплазмі хондроцичта перехідної зони.

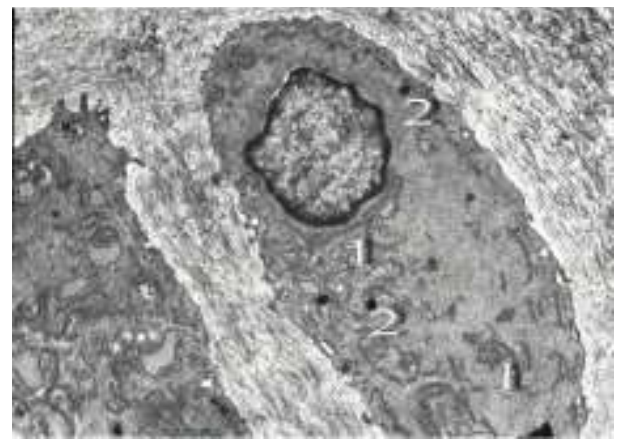

Рис. 4. Хондрощит перехідної зони хряща колінного суглоба щура наприкінці 7-ої доби опіоїдного виливу. Мікрофотографія. 3б. х 8000.

1 - деструкиія органел ичитоплазми хондроцита перехідної зони;

$$
2 \text { - збільшення гранул глікогену. }
$$


За розвитку некротичних змін хондроцитів перехідної зони відзначали ущільнення та різке зменшення ядра, зміну його форми, значне збільшення кількості гетерохроматину, виражену деструкцію органел. У перехідній та базальній зонах збільшувався об'єм територіального та міжтериторіального матриксу, його осміофільність була неоднорідною. Зустрічались ділянки значного просвітлення хрящового матриксу, що майже не містили фібрил колагенових волокон. У базальній зоні відзначали збільшення кількості клітин, у яких ресстрували некротичні зміни. Частіше зустрічались хондроцити 3 різко просвітленою цитоплазмою та виразною деструкцією органел.

В результаті проведеного забору експериментального матеріалу наприкінці 14-ої доби у шурів, що знаходилися під впливом опіоїдного анальгетика в дозі 15 мг/кг на ультраструктурному рівні нами було виявлено, виражені дегенеративно-дистрофічні зміни. Відзначали вогнища руйнування безклітинної пластинки 3 формуванням тріщин та поверхневих узурів. У периферичних ділянках поверхневої зони хряща траплялись ділянки розшарування колагенових волокон та матриксу хряща як це видно на рис.5, що супроводжувалось нагромадженням світло-осміофільної маси, у якій візуалізуються фрагменти зруйнованих фібрил колагенових волокон. Досить часто хондроцити поверхневої зони зазнавали деформації. У ядрі збільшувалась кількість гетерохроматину. Цитоплазма була інтенсивноосміофільна, у ній відзначали деструкцію органел. Матрикс поверхневої зони неоднорідний. Фібрили колагенових волокон розміщувались хаотично, деякі з них зазнавали лізісу. У цитоплазмі хондроцитів перехідної зони відзначали розширення комплексу Гольджі та цистерн гладкої та гранулярної ендоплазматичної сітки як це показано на рис.6. У наслідок руйнування рибосом спостерігали дегрануляцію гранулярної ендоплазматичної сітки. Окремі канальці гранулярної ендоплазматичної сітки були різко розширенні, у них візуалізувались об’ємні вакуолі, заповнені електронносвітлим вмістом. У перинуклеарній зоні відзначали просвітлення цитоплазми. У таких зонах органели не візуалізувались.

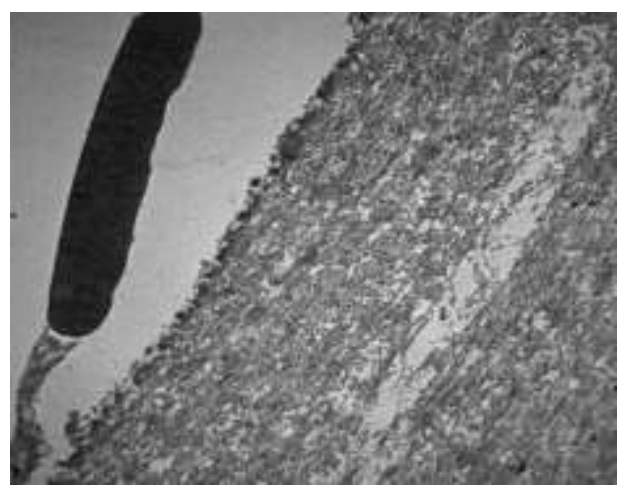

Рис. 5. Поверхнева зона хрящฺа колінного суглоба щура наприкінці 14-ої доби опіоїдного впливу. Мікрофотографія. 3б. х 4000.

1 - руйнування та розшарування фібрил колагенових волокон поверхневої зони.

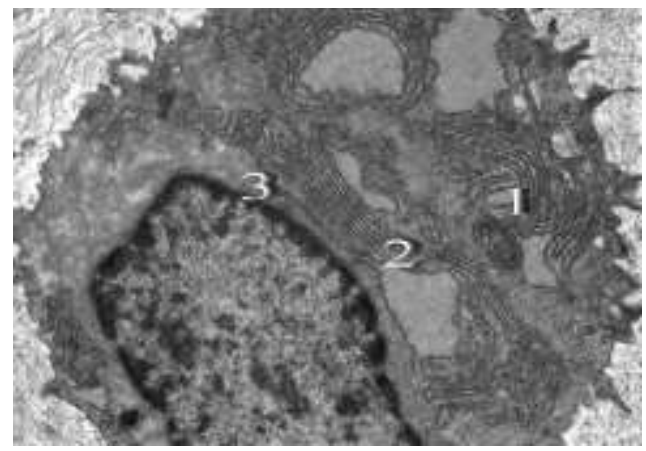

Рис. 6. Хондроџит перехідної зони хряща колінного суглоба щура наприкінці 14-ої доби опіоїдного впливу. Мікрофотографія. 3б. х 14000.

1 - розширення цистерн гладкої та гранулярної ендоплазматичної сітки;

2 - руйнування рибосом; 3 - просвітлення цитоплазми у перинуклеарній зоні. 
Також у цитоплазмі зустрічались вакуолі як це видно на рис.7. дрібні та великі лізосоми, ферменти яких є важливими чинниками, що відповідають за розвиток остеоартрозу.

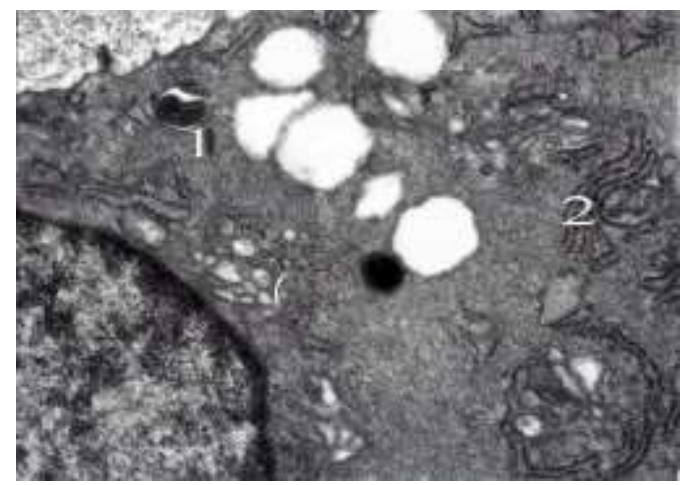

Рис. 7. Хондроџит перехідної зони хряща колінного суглоба щура наприкінщі 14-ої доби опіоїдного виливу. Мікрофотографія. 3б. х 14000.

1 - вакуолі у ичтоолазмі хондроцита перехідної зони; 2 - зменшення кількості рибосом на мембранах гранулярної ендоплазматичної сітки руйнування рибосом.

У перехідній та базальній зоні досить часто зустрічались хондроцити, що зазнавали некротичних змін. Ядро у таких хондроцитах було різко зменшене в об'ємі, неправильної форми, заповнене інтенсивноосміофільним гетерохроматином як це показано на рис.8. У таких хондроцитах реєстрували деструкцію органел. В окремих хондроцитах відзначали руйнування цитоплазматичної мембрани. Поруч таких хондроцитів територіальний матрикс просвітлювався, фібрили колагенових волокон розшаровувались хаотично.

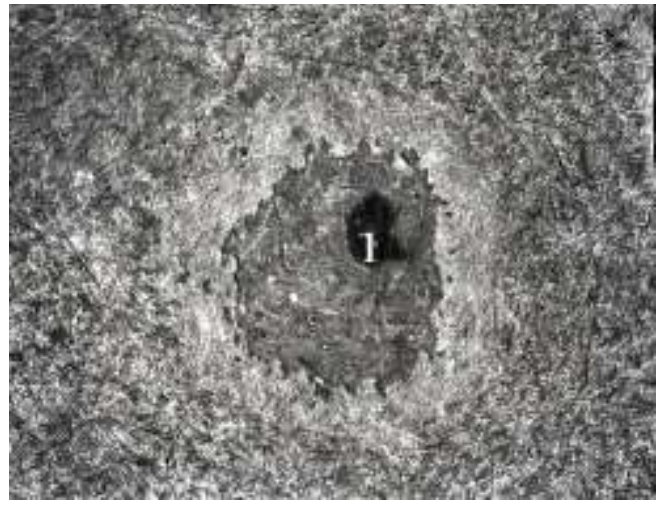

Рис. 8. Хондроџит перехідної зони хряща колінного суглоба щура наприкінці 14-ої доби опіоїдного впливу. Мікрофотографія. 3б. х 6000.

1 - каріопікноз ядра хондрочита перехідної зони.

Також відзначали збільшення об'єму міжтериторіального матриксу, у якому траплялись ділянки просвітлення та руйнування фібрил колагенових волокон.

В результаті проведеного забору експериментального матеріалу наприкінці 21-ої доби у шурів, що знаходилися під впливом опіоїдного анальгетика в дозі 20 мг/кг на ультраструктурному рівні нами було виявлено, виражені альтеративні зміни в хондроцитах, а також деструкцію хрящового матриксу та колагенових волокон. У периферичних зонах хряща на поверхні безклітинної пластинки утворювались глибокі дефекти, дно яких простягалось до перехідної зони. Фібрили колагенових волокон поверхневої зони неоднорідно набрякали, розташовувались хаотично, на багатьох ділянках руйнувались. Також відзначали неоднорідно осміфоільне забарвлення хрящового матриксу поверхневої та перехідної зон. У хондроцитах поверхневої зони виявляли розвиток деструкції, а також ознаки некротичних змін. Проте структура значної кількості хондроцитів поверхневої зони була збережена. У хондроцитах перехідної зони відзначали ураження гранулярної та гладкої ендоплазматичної сітки. Зокрема спостерігали розширення цистерн переважно гладкої ендоплазматичної сітки як це видно на рис.9. 


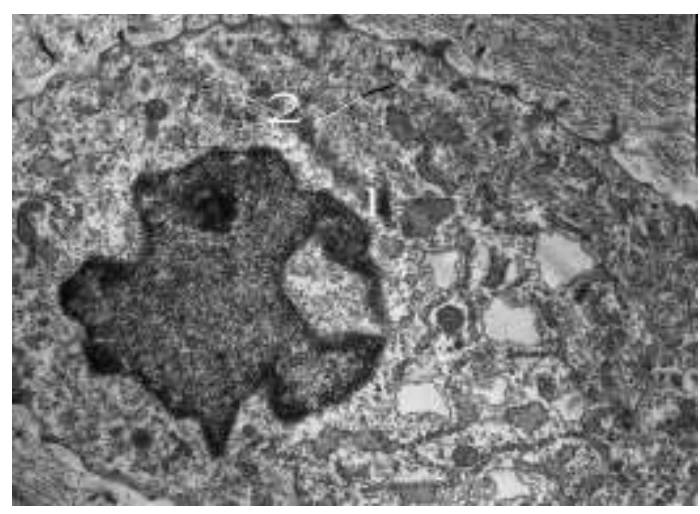

Рис. 9. Хондроџит перехідної зони хряща колінного суглоба щура наприкінці 21-ої доби опіоїдного впливу. Мікрофотографія. 3б. х 8000.

1 - розширення цистерн гладкої ендоплпзматичної сітки; 2 - руйнування рибосом.

Також реєстрували руйнування рибосом гранулярної ендоплазматичної сітки. У цитоплазмі збільшувалась кількість вакуолей як це показано на рис.10. та лізосом. У багатьох хондроцитах перехідної та базальної зон виявили розвиток загибелі клітин як шляхом некрозу, так і апоптозу. У випадку розвитку некрозу ядро різко зменшувалось в об'ємі як це видно на рис.11, набувало неправильної форми, було заповнене переважно гетерохроматином. В деяких хондроцитах ядра не візуалізувались у наслідок каріолізису. Цитоплазма також зазнавала деструкції, у ній нагромаджувались об'ємні вакуолі, включення ліпідів, цитоплазматичні волокна та зерна глікогену, а також значна кількість лізосом.

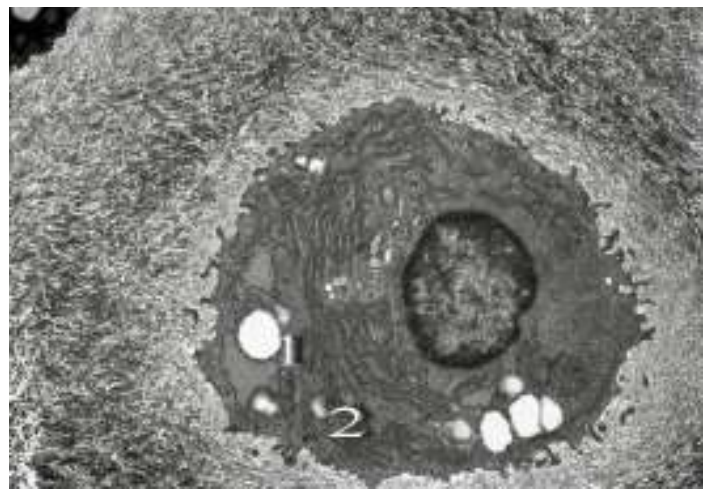

Рис. 10. Хондроцит перехідної зони хряща колінного суглоба щура наприкінщі 21 -ої доби опіӧ̈дного впливу. Мікрофотографія. 3б. х 6000. 1 - збільшеня вакуолей; 2 - лізосоми.

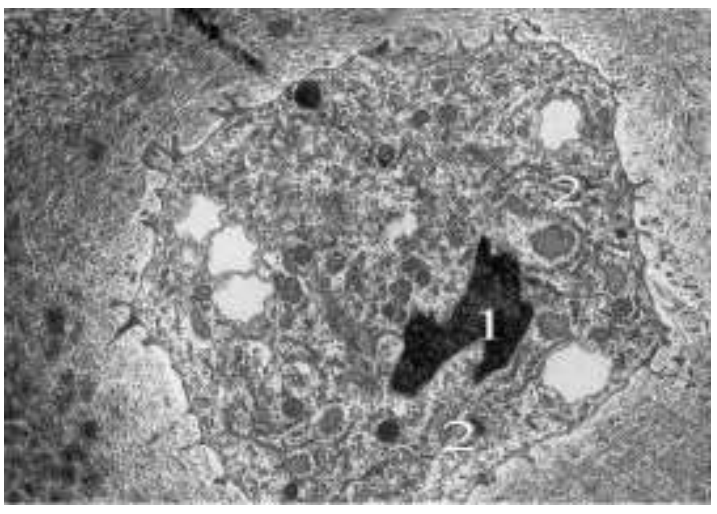

Рис. 11. Хондрочит перехідної та базальної зони хряща колінного суглоба щура наприкінці 21-ої доби опіоїдного впливу. Мікрофотографія. 3б. х 8000.

1 - пікнотичне ядро; 2 - деструкція органел. 
В перехідній зоні локалізуються хондроцити, які зазнають так званої “темно-клітинної загибелі” як це показано на рис.12. Ядро та органели цитоплазми таких хондроцитів ставали інтенсивноосміфофільними, набували однорідного темного вигляду. Зустрічались клітини, які зазнавали повної деструкції.

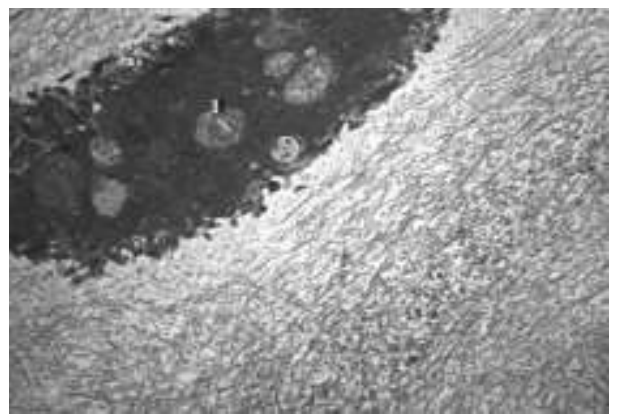

Рис. 12. Загибель хондроцита перехідної зони хряща колінного суглоба щура наприкінці 21-ої доби опіоїдного впливу. Мікрофотографія. 3б. х 10000.

1 - темноклітинна загибель хондроцита;

Візуалізуються лакуни без хондроцитів, електронна щільність матриксу перехідної та базальної зон неоднорідна здебільшого їі щільність знижена. Присутні ділянки де відзначали зростання об'єму міжтериторіального матриксу, з інтенсивним його просвітленням. Досить часто трапляються ділянки 3 вираженою деструкцією фібрил колагенових волокон. Фібрили колагенових волокон місцями набували аморфного вигляду, досить часто не ідентифікувались.

Висновки:

1. Наприкінці першого тижня експериментального опіоїдного впливу нами виявлені ознаки гіпоксичної опіоїдної інтоксикації, що проявлялися розволокненням та руйнуванням фібрил колагенових волокон. У хондроцитах поверхневої зони відзначали ознаки деструкції цитоплазми. Зустрічались ділянки значного просвітлення хрящового матриксу, що майже не містили фібрил колагенових волокон. Візуалізувались хондроцити 3 різко просвітленою цитоплазмою та виразною деструкцією органел.

2. Наприкінці другого тижня експериментального опіоїдного впливу прогресували ознаки опіоїдної інтоксикації, що проявлялися руйнуванням безклітинної пластинки 3 формуванням тріщин та поверхневих узурів. У перехідній та базальній зоні досить часто зустрічались хондроцити, що зазнавали некротичних змін.

3. Наприкінці третього тижня експериментального опіоїдного впливу у багатьох хондроцитах перехідної та базальної зон виявили розвиток загибелі клітин шляхом некрозу та апоптозу. В деяких хондроцитах ядра не візуалізувались у наслідок каріолізису. В перехідній зоні локалізуються хондроцити, які зазнають “темно-клітинної загибелі”.

\section{ЛIТЕРАТУРА}

1. Adrashkin, A. P, Salomatin, I. V, \& Murashov, B. F. (2003). The role of the cardiovascular system in thanatogenesis in opiate addicts of the second stage. From research to treatment standards: Newsletter on the Russian National Congress of Cardiology. Moscow: Russian Society of Cardiology, 18.

2. Raietska, L. V. (2008). Trends in the spread of drug addiction in Ukraine. Fighting organized crime and corruption, 18, 67-76.

3. Treshchinskiy, I. S., Kharchenko, L. A., \& Usenko, V. A. (1998). Some issues of drug addiction and substance abuse in Ukraine. Pharmacist, 4, 15-17.

4. Logash M., \& Pokotylo P. (2013). Some aspects of the history of opiates in the context of nowadays drug addiction problems. Bulletin of Biology and Medicine, 4-1 (42), 129-131.

5. Yakimiv N.Y. (2014). Ultrastructural characteristics structures prismatic-corneal angle eyeball rats after opioid exposure. World of Medicine and Biology, 2 (44), 185-188.

6. Yakimiv NY. (2014). Ultrastructural characteristics of irido-corneal angle of eye of rats on $7^{\text {th }}, 14^{\text {th }}, 21^{\text {st }}$ and $28^{\text {th }}$ days of opioid influence. Ukrainian morphological almanac, 2, 28-31.

7. Paltov Ye.V. (2004). Morphological features of the anatomy of the arterial bed of the neck and maxillofacial area of the rat are normal. Scientific herald of the SZ Gzhytsky Lviv National Academy of Veterinary Medicine, 6-1(1), 113-119. 
8. Paltov Ye.V. (2004). Roengenoanatomy of the arteries of the rat head and neck. Clinical anatomy and operative surgery, 3 (2), 26-29.

9. Paltov Ye.V., Kryvko Yu.Ya., Tomashova S.A., Vil'hova I.V., \& Matkivskyi R.M. (2006). The state of microstructural organization of soft tissues of periodontal disease in white rats in norm and their change at different stages of the course of experimental streptozotocin diabetes mellitus. Bulletin of the Sumy State University, 2 (86), 36-43.

10. Paltov Ye.V., \& Kryvko Yu.Ya. (2006). The ultrastructural organization of soft tissues of periodontal disease in white rats is normal and the dynamics of their changes during the course of streptotsotocininduced experimental diabetes mellitus. World of Medicine and Biology, 3, 35-44.

11. Paltov Ye.V., Chelpanova I.V., Fik V.B., Vil'hova I.V., Kyryk Kh.A., \& Kryvko Yu.Ya. (2017). Pathomorphological changes in layers of retina for six weeks of opioid exposure experiment. World of Medicine and Biology, 2 (60), 146-150.

12. Paltov Ye.V., \& Kryvko Yu.Ya. (2017). Pathological changes in the layers of the retina after eight weeks of opioid influence at the experiment. Bulletin of problems biology and medicine, 4-2 (140), 118-122.

13. Paltov Ye.V., Fik V.B., \& Kryvko Yu.Ya. (2018). Pathomorphological changes in the retina layer at the end of the fourth week of opioid effect, Natural Science Readings abstracts booc. Sosnowiec-Bratislava, 30-32.

14. Fik V.B., Paltov E.V., Lohash M.V., \& Kryvko Yu.Ya. (2017). Pecularities of morphological manifestation of the periodontal tissue in experimental animals against the ground of a short-term effect of opioid analgesic. Deutsch. Wissenscaftsch, 2, 54-58.

15. Fik V.B., Kryvko Yu.Ya., \& Paltov E.V. (2018). Microstructural changes of periodontal tissue under the action of opioid analgesics in the early stages. Bukovinian Medical Herald, 22-1 (85), 141-148.

16. Fik V.B., Paltov E.V., \& Kryvko Yu.Ya. (2018). Morphofunctional peculiarities of the periodontal tissue under conditions of simulated eight-week opioid effect. Deutscher Wissenschaftscherold German Science Herald, 1, 14-17. DOI:10.19221/201814.

17. Onisco, RM, Paltov, YV, Fik, VB, Fitkalo, OS. (2013). Ukraine. Patent No. 76564. Kyiv: Ukrainian Institute of Intellectual Property (Ukrpatent).

18. Glauert A.M. (1975). Fixation, Dehydration and Embedding of Biological Specimens. In: Practical methods in electron microscpi. North-Hollond: American Elsevier.

19. Stempak J.G., \& Ward R.T. (1964). An improved staining method for electron microscopy. J Cell Biol, 22 (3), 697-701.

20. Reynolds E.S. (1963). The use of lead citrate at high $\mathrm{pH}$ as an electronopague stain in electron microscopy. J Cell Biol, 17, 208-212. 